\title{
Production of Aromatic Hydrocarbons from $\mathrm{C}_{3}, \mathrm{C}_{4}$-alkanes over Zeolite Catalysts
}

\author{
Anton A. Vosmerikova , Ludmila N. Vosmerikova ${ }^{a}$, \\ Irina G. Danilova ${ }^{b}$ and Alexander V. Vosmerikov*a \\ ${ }^{a}$ Institute of Petroleum Chemistry SB RAS \\ 4 Akademichesky, Tomsk, 634055, Russia \\ ${ }^{b}$ Boreskov Institute of Catalysis SB RAS \\ 5 Akademika Lavrent'eva, Novosibirsk, 630090, Russia
}

Received 25.12.2018, received in revised form 21.01.2019, accepted 10.02.2019

\begin{abstract}
An aluminosilicate and a galloaluminosilicate of MFI structure are synthesized by the hydrothermal method from alkaline aluminosilicates. Structural, acidic, and catalytic properties of synthesized zeolites are investigated in the course of dehydrocyclization of lower alkanes. It is found out that aromatic hydrocarbons are formed in their highest amount when butane is converted over the galloaluminosilicate, while the lowest amount of them is resulted from the conversion of propane over the aluminosilicate. It is shown that to achieve the nigh conversion of propane and butane and the yield of desired product in the presence of the catalysts under study, the process temperature during the propane conversion should be 50 degrees higher under the same other reaction conditions.
\end{abstract}

Keywords: aluminosilicate, galloaluminosilicate, propane, butane, conversion, selectivity, aromatic hydrocarbons.

Citation: Vosmerikov A.A., Vosmerikova L.N., Danilova I.G., Vosmerikov A.V. Production of aromatic hydrocarbons from $\mathrm{C}_{3}, \mathrm{C}_{4}$-alkanes over zeolite catalysts, J. Sib. Fed. Univ. Chem., 2019, 12(1), 144-154. DOI: 10.17516/1998-2836-0114.

(C) Siberian Federal University. All rights reserved

* Corresponding author E-mail address: antonvosmerikov@gmail.com 


\title{
Получение ароматических углеводородов \\ из $\mathrm{C}_{3}, \mathrm{C}_{4}$-алканов на цеолитных катализаторах
}

\author{
А.А. Восмериков ${ }^{\mathrm{a}}$, Л.Н. Восмерикова ${ }^{\mathrm{a}}$, \\ И.Г. Данилова ${ }^{6}$, А.В. Восмериков ${ }^{a}$ \\ ${ }^{a}$ Институт химии нефти СО РАН \\ Россия, 634055, Томск, пр. Академический, 4 \\ ${ }^{6}$ Институт катализа им. Г.К. Борескова СО РАН \\ Россия, 630090, Новосибирск, пр. Академика Лаврентьева, 5
}

Гидротермальным способом из щелочных алюмокремнегелей синтезированы алюмосиликат и галлоалюмосиликат структурного типа MFI. Исследованы структурные, кислотные и каталитические свойства полученных цеолитов в процессе дегидроциклизации низших алканов. Установлено, что наибольшее количество ароматических углеводородов образуется при превращении бутана на галлоалюмосиликате, а наименьшее - при превращении пропана на алюмосиликате. Показано, что для достижения близкой конверсии пропана и бутана и выхода целевого продукта в присутствии изученных катализаторов температура процесса при превращении пропана должна быть на 50 градусов выще при одинаковых других условиях реакиии.

Ключевые слова: алюмосиликат, галлоалюмосиликат, пропан, бутан, конверсия, селективность, ароматические углеводороды.

\section{Введение}

В настоящее время весьма актуальна проблема получения нефтехимических продуктов из природных, попутных и отходящих газов нефтедобывающих и нефтеперерабатывающих предприятий. Необходимость рациональной утилизации попутного нефтяного газа обусловлена сжиганием его в огромных количествах на факельных установках в нефтедобывающих регионах из-за невозможности или экономической нецелесообразности транспортирования на газоперерабатывающие комплексы. По различным оценкам в Российской Федерации за год сжигается в факелах от 3,5 до 14,5 млрд м ${ }^{3}$ попутного газа. Из-за сжигания газа Россия ежегодно теряет около 140 млрд рублей, упущенная выгода от каждого не вовлеченного в переработку миллиарда кубических метров попутного нефтяного газа оценивается в 270 млн долларов. В результате этого не только теряется невосполнимый энергетический ресурс, являющийся к тому же и ценным химическим сырьем, но и наносится огромный ущерб окружающей среде. Основными компонентами этих природных углеводородных газов, наряду с метаном, считают пропан и бутан. Дальнейшее совершенствование существующих технологических процессов, повышение их эффективности и создание новых технологий невозможно без разработки и внедрения в практику катализаторов, обладающих более высокой активностью и селективностью, что определяет актуальность и цель проведения исследований в этом направлении. Наиболь- 
шие успехи связаны с использованием цеолитов структурного типа MFI [1]. В частности, с использованием таких катализаторов удается превращать низшие алканы - компоненты природного и попутного нефтяного газов в ароматические углеводороды (АрУ) [2-5]. Целью настоящей работы явилось изучение закономерностей превращения $\mathrm{C}_{3}, \mathrm{C}_{4}$-алканов в ароматические углеводороды на цеолитных катализаторах, модифицированных активными металлическими компонентами.

\section{Экспериментальная часть}

\section{Получение чеолитных катализаторов}

Bысококремнеземные цеелиты (алюмосиликаты, АC) с силикатным модулем 40 получали гидротермальным синтезом из щелочных алюмокремнегелей в автоклавах из нержавеющей стали с тефлоновыми вставками при температуре $170-175{ }^{\circ} \mathrm{C}$ в течение 5 сут. Исходную реакционную смесь готовили путем добавления к жидкому стеклу $\left(29 \% \mathrm{SiO}_{2}, 9 \% \mathrm{Na}_{2} \mathrm{O}, 62\right.$ \% $\left.\mathrm{H}_{2} \mathrm{O}\right)$ водного раствора нитрата алюминия $\mathrm{Al}\left(\mathrm{NO}_{3}\right)_{3} \cdot 9 \mathrm{H}_{2} \mathrm{O}$, в качестве темплата использовали гексаметилендиамин (ГМДА), при интенсивном перемешивании, $\mathrm{pH}$ реакционной смеси регулировали добавлением 0,1 N раствора азотной кислоты. Галлоалюмосиликат (Ga-AC) был получен путем частичной замены алюминия на галлий в исходном алюмокремнегеле $\left(\mathrm{SiO}_{2} /\right.$ $\left.\mathrm{Al}_{2} \mathrm{O}_{3}+\mathrm{Ga}_{2} \mathrm{O}_{3}=40\right)$. Концентрация оксида галлия в цеолите составляла $\left[\mathrm{Ga}_{2} \mathrm{O}_{3}\right]=1,85$ мас. \%.

После окончания кристаллизации твердую фазу отделяли от жидкой фильтрованием, промывали дистиллированной водой до $\mathrm{pH}$ промывных вод $\leq 9$, сушили в атмосфере воздуха при $110{ }^{\circ} \mathrm{C}$ в течение 24 ч и прокаливали для удаления ГМДА при $550{ }^{\circ} \mathrm{C}$ в течение 8 ч.

Для перевода в активную Н-форму полученные образцы обрабатывали 25\%-ным водным раствором $\mathrm{NH}_{4} \mathrm{Cl}$ при $90{ }^{\circ} \mathrm{C}$ в течение 2 ч при расходе 10 г раствора на 1 г цеолита. После удаления катионов натрия цеолиты в $\mathrm{NH}_{4}$-форме сушили при $110{ }^{\circ} \mathrm{C}$ и прокаливали в атмосфере воздуха при $540{ }^{\circ} \mathrm{C}$ в течение 6 ч для получения Н-формы цеолита.

Данные о составе и степени кристалличности полученных катализаторов представлены в табл. 1. Введение в состав цеолита галлия на стадии гидротермального синтеза приводит к небольшому снижению степени кристалличности цеолитного катализатора, которая для обоих образцов является высокой.

\section{Каталитические испьтания цеолитных катализаторов}

Для изучения процесса превращения низших алканов в жидкие продукты на исследуемых катализаторах использовалась стендовая установка проточного типа. Конверсию пропана

Таблица 1. Состав и степень кристалличности цеолитных катализаторов

Table 1. Composition and degree of crystallinity of zeolite catalysts

\begin{tabular}{|c|c|c|c|c|}
\hline \multirow{2}{*}{ Образец } & \multicolumn{2}{|c|}{ Концентрация, мас. \% } & $\begin{array}{c}\text { Мольное отношение } \\
\mathrm{SiO}_{2} / \mathrm{Al}_{2} \mathrm{O}_{3}+\mathrm{Me}_{2} \mathrm{O}_{3}\end{array}$ & $\begin{array}{c}\text { Степень } \\
\text { кристалличности, \% }\end{array}$ \\
\cline { 2 - 3 } $\mathrm{AC}$ & $\mathrm{Me}_{2} \mathrm{O}_{3}$ & $\mathrm{Al}_{2} \mathrm{O}_{3}$ & 40 & 100 \\
\hline $\mathrm{Ga}-\mathrm{AC}$ & - & 4,07 & 40 & 97 \\
\hline
\end{tabular}


(степень чистоты 99,95 \% об.) и бутана (степень чистоты 99,20 \% об.) осуществляли при атмосферном давлении с варьированием температуры реакции от 400 до $600{ }^{\circ} \mathrm{C}$, объемная скорость подачи сырья составляла $500 \mathrm{ч}^{-1}$. Испытание катализатора при каждой температуре длилось 60 мин, до и после каждого опыта реактор с образцом продували газообразным азотом. Продукты реакции анализировали методом ГЖХ с использованием хроматографа «ХроматэкКристалл 5000.2». Для определения состава жидкой фазы использовали капиллярную колонку BP-1 PONA (100 м х 0.25 мм х 0.5 мкм), а для определения состава газовой фазы - капиллярную GS-Gas-Pro (60 м х 0.32 мм) и набивную Carbosieve S-II (4 м х 2 мм, 60/80 меш) колонки. При проведении экспериментов определяли степень превращения исходных алканов, выход газообразных и жидких продуктов, а также рассчитывали селективность образования продуктов реакции.

\section{Физико-химические методы исследования цеолитных катализаторов}

Кислотные свойства образцов изучали методом температурно-программируемой десорбции (ТПД) аммиака [6] и инфракрасной спектроскопии (ИКС) с использованием низкотемпературной адсорбции молекулы-зонда СО [7, 8].

Термодесорбцию аммиака проводили на термодесорбционной установке с программированным нагревом образца. Силу кислотных центров катализатора оценивали по температурным максимумам на термодесорбционной кривой, а их концентрацию определяли по количеству аммиака, десорбирующегося в момент фиксации десорбционных пиков, и выражали в мкмолях на 1 г катализатора.

ИК-спектры регистрировали на ИК-Фурье спектрометре FTIR-8300 фирмы Shimadzu в области 700-6000 см${ }^{-1}$ с разрешением $4 \mathrm{~cm}^{-1}$ и числом сканов, равным 500. Перед регистрацией

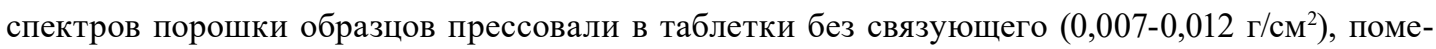
щали в кварцевую ячейку и тренировали в вакууме при $400{ }^{\circ} \mathrm{C}$ до остаточного давления $\mathrm{p}<10^{-3}$ мбар. Адсорбцию СО проводили при температуре жидкого азота при увеличении давления СО от 0.1 до 10 мбар.

Измерения удельной поверхности и характера распределения пор по размерам осуществляли на приборе Micromeritics ASAP 2020 (США). Расчет удельной поверхности исследуемого образца проводили с использованием многоточечного метода БЭТ. Объем и размер пор определяли с использованием модели ВЈН (Barett-Joyner-Halenda) из данных изотерм адсорбции и десорбции при относительном давлении $\mathrm{P} / \mathrm{Po}=0,99$.

\section{Результаты и их обсуждение}

Кислотные и структурные характеристики цееолтных катализаторов

Одной из важных характеристик, определяющих активность цеолитных катализаторов, являются их кислотно-основные свойства, которые зависят от состава каталитических систем. Результаты исследования кислотных свойств образцов приведены в табл. 2. Алюмосиликат имеет два типа кислотных центров, о чем свидетельствует наличие двух форм десорбции аммиака на термодесорбционном спектре: слабокислотные с температурой максимума пика $\mathrm{T}_{\text {макс. }}=205^{\circ} \mathrm{C}$ и сильнокислотные с $\mathrm{T}_{\text {макс. }}=425^{\circ} \mathrm{C}$. Концентрация слабых кислотных центров составляет 676 мкмоль/г, а сильных - 251 мкмоль/г. Введение галлия в цеолит в процессе гидро- 
Таблица 2. Кислотные и структурные характеристики цеолитных катализаторов

Table 2. Acidic and structural characteristics of zeolite catalysts

\begin{tabular}{|c|c|c|c|c|c|c|c|c|}
\hline \multirow{2}{*}{ Образец } & \multicolumn{2}{|c|}{$\mathrm{T}_{\text {макс., }}{ }^{\circ} \mathrm{C}$} & \multicolumn{3}{|c|}{$\begin{array}{c}\text { Концентрация, } \\
\text { мкмоль/г }\end{array}$} & \multirow[t]{2}{*}{$\mathrm{S}_{\text {уд }}, \mathrm{M}^{2} / \Gamma$} & \multirow{2}{*}{$\begin{array}{c}\text { Суммарный } \\
\text { объем пор, } \text { см³ }^{3} \Gamma\end{array}$} & \multirow{2}{*}{$\begin{array}{c}\text { Средний } \\
\text { диаметр пор, нм }\end{array}$} \\
\hline & $T_{\mathrm{I}}$ & $T_{\mathrm{II}}$ & $C_{\mathrm{I}}$ & $C_{\mathrm{II}}$ & $C_{\Sigma}$ & & & \\
\hline $\mathrm{AC}$ & 205 & 425 & 676 & 251 & 927 & 450 & 0,18 & 6,3 \\
\hline Ga-AC & 200 & 425 & 531 & 330 & 861 & 344 & 0,25 & 6,5 \\
\hline
\end{tabular}

Примечание. $\mathrm{T}_{\mathrm{I}}, \mathrm{T}_{\mathrm{II}}$ - температуры максимумов низко- и высокотемпературных пиков на термодесорбционных кривых; $\mathrm{C}_{\mathrm{I}}, \mathrm{C}_{\mathrm{II}}$ и $\mathrm{C}_{\Sigma}$ - концентрации слабых и сильных кислотных центров и их сумма, соответственно. $\mathrm{S}_{\text {уд. }}-$ удельная поверхность.

термального синтеза приводит к изменению кислотных свойств и, прежде всего, к изменению концентрации кислотных центров: уменьшается концентрация слабых кислотных центров и увеличивается содержание высокотемпературных кислотных центров. Это объясняется тем, что при введении галлия в цеолит образуются новые, более сильные активные центры с высокой энергией удерживания аммиака.

Исследования структурных характеристик катализаторов показали, что алюмосиликат обладает более высокой удельной поверхностью, но меньшим суммарным объемом пор (табл. 2). При этом образцы AC и Ga-AC содержат поры, характеризующиеся практически одинаковым средним диаметром - 6,3 и 6,5 нм соответственно.

Исследования галлоалюмосиликата методом ИК-спектроскопии адсорбированных молекул показали, что в спектре образца в области валентных колебаний ОН-групп наблюдаются полосы поглощения нескольких типов гидроксильных групп (рис. 1). Широкая п.п. 3300-3500 см ${ }^{-1}$ относится к водородносвязанным ОН-группам. Мостиковые гидроксильные группы $\mathrm{Si}-\mathrm{O}(\mathrm{H})-\mathrm{Al}$ или $\mathrm{Si}-\mathrm{O}(\mathrm{H})-\mathrm{Ga}$ в каналах цеолита характеризуются интенсивной п.п. 3605-3615 см-1. Полосу поглощения $3660 \mathrm{~cm}^{-1}$ можно отнести к мостиковым Al-O(H)-Alгруппам, частично связанным с решеткой цеолита; в данную п.п. могут вносить вклад внерешеточные $\mathrm{GaO}-\mathrm{OH}-г$ руппы, поглощение которых обычно наблюдают около 3670-3772 $\mathrm{cm}^{-1}$. Полоса поглощения $3745 \mathrm{~cm}^{-1}$ относится к терминальным Si-OH-группам, а п.п. $3775 \mathrm{~cm}^{-1}-$ к внерешеточным терминальным Al-ОН-группам. Плечо при 3730-3735 см-1 может характеризовать кислотные $\mathrm{Si-OH-группы} \mathrm{на} \mathrm{внешней} \mathrm{поверхности} \mathrm{кристаллитов} \mathrm{цеолита,} \mathrm{располо-}$ женные в непосредственной близости от льюисовских кислотных центров, образованных трехкоординированными атомами $\mathrm{Al}$ или $\mathrm{Si}$.

В области поглощения карбонильных групп водородносвязанным комплексам СО с сильными бренстедовскими кислотными центрами (мостиковые $\mathrm{Si}-\mathrm{O}(\mathrm{H})$-Al-группы) соответствует п.п. $v_{\mathrm{CO}}$ 2175-2174 cм${ }^{-1}$, которая появляется в спектре уже при низких давлениях адсорбата (рис. 2). При более высоких давлениях СО происходит уширение этой полосы, появление асимметричности и сдвиг до $v_{\mathrm{CO}} 2168 \mathrm{~cm}^{-1}$, что характерно для образования комплексов СО с внерешеточными Al-O(H)-Al-группами. При давлении CO, близком к равновесному, в спектрах наблюдается появление полосы поглощения $v_{\mathrm{CO}} 2157 \mathrm{~cm}^{-1}$, соответствующей комплексу СО со слабокислыми силанольными группами с $v_{\mathrm{O}-\mathrm{H}}=3745 \mathrm{~cm}^{-1}$. Кроме того, в спектре наблюдается появление п.п. $2138 \mathrm{~cm}^{-1}$, что характерно для капиллярной конденсации СО в каналах цеолита. 


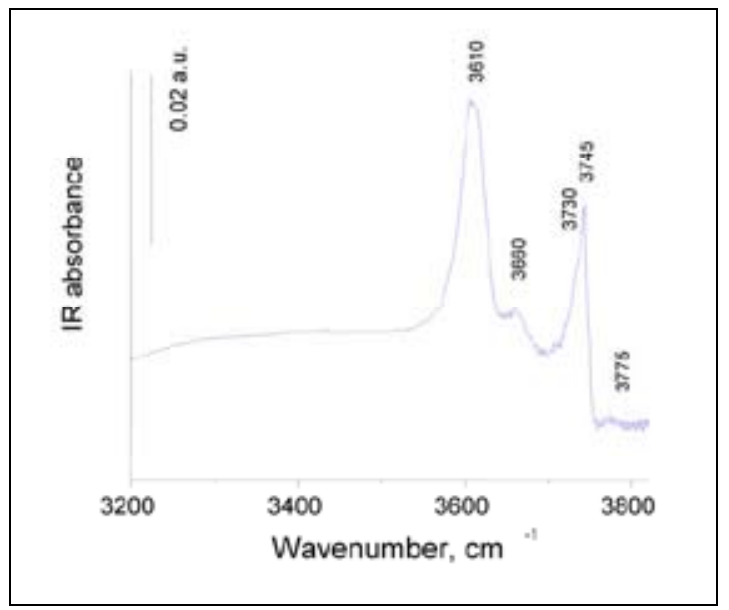

Рис. 1. ИК-спектры галлоалюмосиликата в области колебаний поверхностных гидроксильных групп

Fig. 1. IR spectra of the galloaluminosilicate in the region of vibrations of surface hydroxyl groups

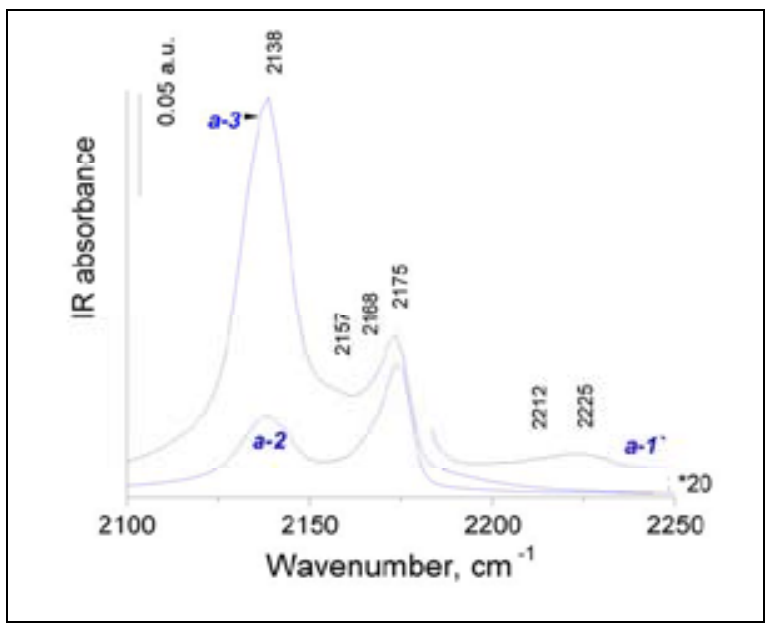

Рис. 2. ИК-спектры в области колебаний карбонильных групп после адсорбции 0,1 (a-1'), 1 (a-2) и 5 мбар CO (а-3) при температуре жидкого азота на галлоалюмосиликате

Fig. 2. IR spectra in the region of carbonyl group vibrations after CO adsorption 0.1 (a-1), 1 (a-2) and 5 mbar (a-3) at the liquid nitrogen temperature over the galloaluminosilicate

В ИК-спектрах адсорбированного СО комплексам СО с льюисовскими кислотными цен-

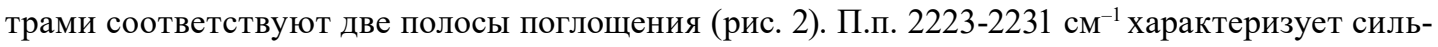
ные центры, представляющие собой ионы $\mathrm{Al}^{3+}$ в дефектном октаэдре [9]; п.п. 2216-2206 cм$^{-1}$ относится к центрам средней силы (изолированные ионы $\mathrm{Ga}^{3+}$ или малые кластеры $\mathrm{Ga}_{2} \mathrm{O}_{3}$ ).

Таким образом, исследования кислотных и структурных свойств цеолитных катализаторов показали, что образцы отличаются распределением кислотных центров по концентрации и величиной удельной поверхности, что, в свою очередь, сказывается на их каталитических свойствах в превращении $\mathrm{C}_{3}, \mathrm{C}_{4}$-алканов, так как определенные активные центры ответственны за протекание той или иной химической реакции. 


\section{Каталитические свойства цеолитных катализаторов}

Немодифицированный цеолит в Н-форме проявляет относительно невысокую активность в процессе превращения пропана в ароматические углеводороды (табл. 3). В образующихся на нем продуктах реакции содержится большое количество метана и низших олефинов. Конверсия пропана и выход ароматических углеводородов, образующихся при $600{ }^{\circ} \mathrm{C}$ на алюмосиликатном катализаторе, составляют соответственно 94 и 34,4 \%. Бутан на этом образце интенсивно превращается уже при температуре реакции $400{ }^{\circ} \mathrm{C}$, а заметное образование ароматических углеводородов наблюдается при $450{ }^{\circ} \mathrm{C}$ и выше. В то же время выход ароматических углеводородов при превращении бутана практически не отличается от количества ароматических углеводородов, образующихся при конверсии пропана. Однако при этом температура процесса при превращении пропана должна быть на $50{ }^{\circ} \mathrm{C}$ выше, чем в случае конверсии бутана. Так, выход ароматических углеводородов при превращении бутана составляет $34,9 \%$ при температуре реакции $550{ }^{\circ} \mathrm{C}$, близкое количество ароматических углеводородов образуется при превращении пропана только при $600{ }^{\circ} \mathrm{C}$.

Использование галлоалюмосиликата в процессе превращения $\mathrm{C}_{3}, \mathrm{C}_{4}$-алканов позволяет значительно повысить выход ароматических углеводородов и снизить образование метана и этана (табл. 3). На образце $\mathrm{Ga}-\mathrm{AC}$ заметное превращение пропана начинается при температуре реакции $450{ }^{\circ} \mathrm{C}$. С повышением температуры процесса конверсия пропана резко возрастает и

Таблица 3. Основные показатели процесса превращения пропана и бутана на цеолитных катализаторах Table 3. Key indicators of the process of propane and butane conversion over zeolite catalysts

\begin{tabular}{|c|c|c|c|c|c|c|c|c|}
\hline Сырье & $\mathrm{T},{ }^{\circ} \mathrm{C}$ & $\mathrm{X}, \%$ & $\mathrm{~S}_{1}, \%$ & $\mathrm{~S}_{2}, \%$ & $\mathrm{~S}_{3}, \%$ & $\mathrm{~S}_{4}, \%$ & $\mathrm{~S}_{5}, \%$ & $\mathrm{~A}, \%$ \\
\hline \multicolumn{9}{|c|}{ Катализатор АC } \\
\hline \multirow{5}{*}{ пропан } & 400 & 8 & 0,6 & 24,9 & 65,6 & 6,2 & 2,7 & 0,2 \\
\hline & 450 & 20 & 1,2 & 43,5 & 40,9 & 9,5 & 4,9 & 0,9 \\
\hline & 500 & 40 & 2,3 & 65,1 & 12,3 & 12,9 & 7,4 & 3,0 \\
\hline & 550 & 78 & 2,5 & 50,0 & 1,0 & 9,6 & 36,9 & 28,6 \\
\hline & 600 & 94 & 3,2 & 51,5 & 0,1 & 8,7 & 36,5 & 34,4 \\
\hline \multirow{4}{*}{ бутан } & 400 & 76 & 0,1 & 4,5 & 91,6 & 2,4 & 1,4 & 1,0 \\
\hline & 450 & 91 & 0,4 & 12,4 & 63,6 & 3,6 & 20,0 & 18,3 \\
\hline & 500 & 96 & 1,2 & 26,9 & 39,6 & 6,5 & 25,8 & 24,8 \\
\hline & 550 & 99 & 2,0 & 38,9 & 15,5 & 8,4 & 35,2 & 34,9 \\
\hline \multicolumn{9}{|c|}{ Катализатор Ga-AC } \\
\hline \multirow{5}{*}{ пропан } & 400 & 11 & 4,8 & 27,9 & 47,0 & 5,8 & 14,5 & 1,6 \\
\hline & 450 & 26 & 7,8 & 51,9 & 16,1 & 7,7 & 16,5 & 4,3 \\
\hline & 500 & 68 & 4,6 & 34,6 & 1,9 & 4,6 & 54,3 & 36,6 \\
\hline & 550 & 92 & 4,4 & 34,7 & 0,3 & 4,0 & 56,6 & 51,8 \\
\hline & 600 & 100 & 4,4 & 37,6 & 0,1 & 5,4 & 52,5 & 52,5 \\
\hline \multirow{4}{*}{ бутан } & 400 & 75 & 0,9 & 6,3 & 77,1 & 2,0 & 13,7 & 10,3 \\
\hline & 450 & 92 & 1,8 & 13,8 & 50,6 & 3,0 & 30,8 & 27,5 \\
\hline & 500 & 98 & 2,9 & 24,1 & 28,7 & 4,4 & 39,9 & 39,1 \\
\hline & 550 & 100 & 3,4 & 31,2 & 12,8 & 5,6 & 47,0 & 47,0 \\
\hline
\end{tabular}

Примечание. Т - температура процесса; X - конверсия; $\mathrm{S}_{1}, \mathrm{~S}_{2}, \mathrm{~S}_{3}, \mathrm{~S}_{4}$ и $\mathrm{S}_{5}$ - селективность образования водорода, алканов $\mathrm{C}_{1}-\mathrm{C}_{2}$, алканов $\mathrm{C}_{3}-\mathrm{C}_{5}$, алкенов $\mathrm{C}_{2}-\mathrm{C}_{4}$ и ароматических углеводородов соответственно; $\mathrm{A}$ - выход ароматических углеводородов. 
при $600{ }^{\circ} \mathrm{C}$ достигает $100 \%$. Значительное образование ароматических углеводородов наблюдается при $500{ }^{\circ} \mathrm{C}$, а максимальный их выход достигает $52,5 \%$ при $600^{\circ} \mathrm{C}$. Превращение бутана

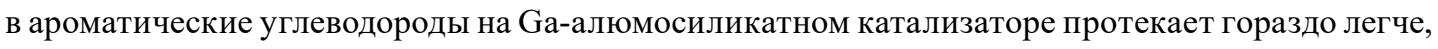
чем пропана, при этом заметное их образование начинается уже при $400{ }^{\circ} \mathrm{C}$. $\mathrm{C}$ ростом температуры процесса выход ароматических углеводородов увеличивается, при $550{ }^{\circ} \mathrm{C}$ он достигает 47,0 \% при полном превращении бутана.

Данные по влиянию состава исходного газообразного сырья (пропан и бутан) на состав и выход образующихся продуктов его превращения на алюмосиликате и галлоалюмосиликате приведены на рис. 3 и в табл. 4. Основными продуктами превращения $\mathrm{C}_{3}, \mathrm{C}_{4}$-алканов на исследуемых катализаторах являются газообразные $\mathrm{C}_{1}-\mathrm{C}_{5}$ и жидкие углеводороды. Катализат содер-

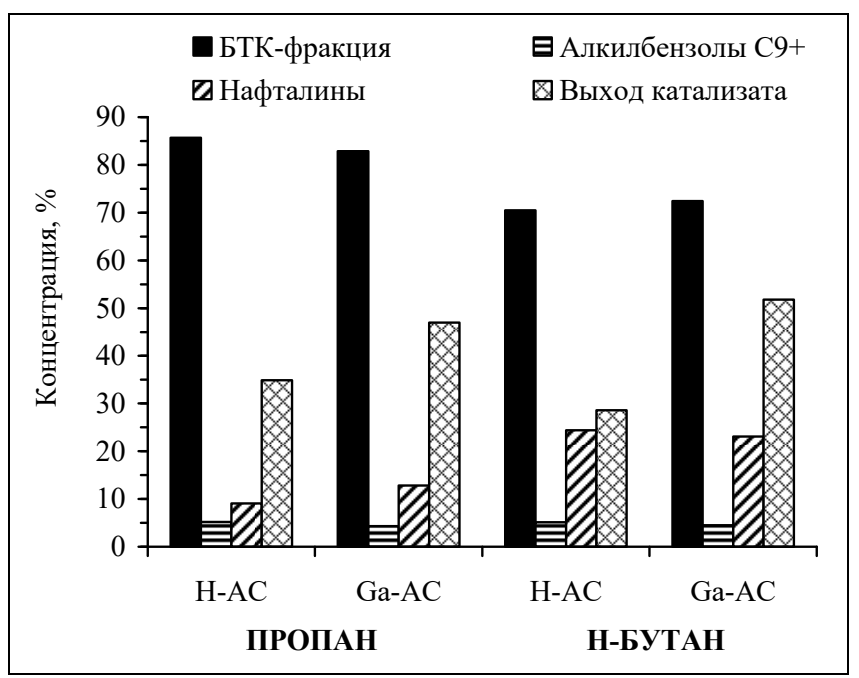

Рис. 3. Состав жидких продуктов превращения $\mathrm{C}_{3}, \mathrm{C}_{4}$-алканов и выход катализата на цеолитных катализаторах $\left(\mathrm{T}=550^{\circ} \mathrm{C}\right)$

Fig. 3. Composition of liquid products of $\mathrm{C}_{3}, \mathrm{C}_{4}$-alkane conversion and yield of catalyzate over zeolite catalysts $\left(\mathrm{T}=550^{\circ} \mathrm{C}\right)$

Таблица 4. Состав газообразных продуктов превращения $\mathrm{C}_{3}, \mathrm{C}_{4}$-алканов на цеолитных катализаторах $\left(\mathrm{T}=550^{\circ} \mathrm{C}\right)$

Table 4. Composition of gaseous products of the $\mathrm{C}_{3}, \mathrm{C}_{4}$-alkane conversion over zeolite catalysts $\left(\mathrm{T}=550{ }^{\circ} \mathrm{C}\right)$

\begin{tabular}{|c|c|c|c|c|c|}
\hline \multirow{2}{*}{ Образец } & \multicolumn{6}{|c|}{ Состав газообразных продуктов, \% мас. } \\
\cline { 2 - 6 } & $\mathrm{H}_{2}$ & $\mathrm{CH}_{4}$ & $\mathrm{C}_{2} \mathrm{H}_{6}$ & Алкены $\mathrm{C}_{2}-\mathrm{C}_{4}$ & Алканы $\mathrm{C}_{3}-\mathrm{C}_{5}$ \\
\hline \multicolumn{6}{|c|}{ пропан } \\
\hline $\mathrm{AC}$ & 2,7 & 36,2 & 18,0 & 10,4 & 32,7 \\
\hline $\mathrm{Ga}-\mathrm{AC}$ & 8,1 & 45,3 & 20,9 & 7,6 & 18,1 \\
\hline \multicolumn{7}{|c|}{ бутан } \\
\hline $\mathrm{AC}$ & 3,1 & 30,8 & 28,5 & 12,8 & 24,8 \\
\hline $\mathrm{Ga}-\mathrm{AC}$ & 6,3 & 32,2 & 26,2 & 10,5 & 24,8 \\
\hline
\end{tabular}


жит смесь ароматических углеводородов, состоящую преимущественно из бензола, толуола и ксилолов (БТК-фракция), в небольших количествах также присутствуют алкилбензолы $\mathrm{C}_{9+}$, нафталин и алкилнафталины (рис. 3). Газообразные продукты состоят в основном из метана и этана, а также в небольшом количестве присутствуют водород, алканы $\mathrm{C}_{3}-\mathrm{C}_{5}$ и олефины $\mathrm{C}_{2}-\mathrm{C}_{4}$ (табл. 4). Максимальное количество ароматических углеводородов $(52,5 \%)$ при $600{ }^{\circ} \mathrm{C}$ образуется при превращении пропана на галлоалюмосиликате. Можно отметить образование большого количества БТК-фракции при превращении $\mathrm{C}_{3}, \mathrm{C}_{4}$-алканов, причем при превращении бутана на исследуемых катализаторах выход этой фракции ниже, чем в случае превращения пропана. Соответственно, в составе катализата, образующегося при превращении бутана, содержится больше нафталиновых углеводородов по сравнению с составом катализата, полученном при превращении пропана. Выход алкилбензолов, полученных при превращении пропана и бутана, отличается незначительно.

В составе газообразных продуктов превращения пропана на галлоалюмосиликате содержится больше водорода, метана и меньше олефинов $\mathrm{C}_{2}-\mathrm{C}_{4}$ и алканов $\mathrm{C}_{3}-\mathrm{C}_{5}$ по сравнению с продуктами, полученными на алюмосиликате. Низкая концентрация олефинов в продуктах реакции указывает на то, что они являются промежуточными продуктами, которые активно вступают в дальнейшие взаимодействия, приводящие к получению ароматических углеводородов. Качественный и количественный состав газообразных продуктов превращения бутана на исследуемых катализаторах отличается незначительно.

При оценке селективности процесса ароматизации $\mathrm{C}_{3}, \mathrm{C}_{4}$-алканов на исследуемых цеолитных катализаторах необходимо учитывать тот факт, что сравнение проводится при различных значениях конверсии исходных газообразных углеводородов. На рис. 4 приведена зависимость выхода ароматических углеводородов от конверсии исходных углеводородов. Как видно из представленных данных, для галлоалюмосиликата при превращении пропана

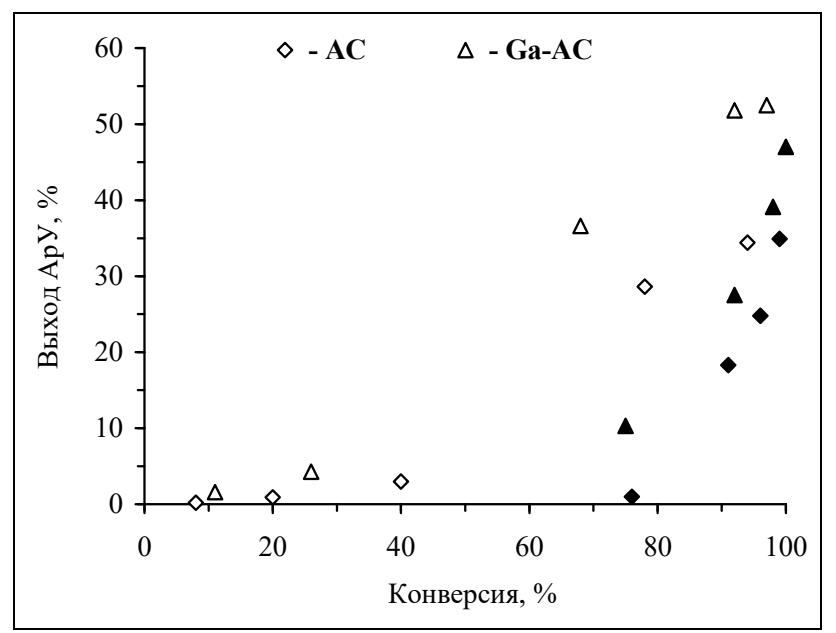

Рис. 4. Зависимость выхода ароматических углеводородов, образующихся на цеолитных катализаторах, от конверсии исходного газообразного сырья: светлые значки - пропан, темные значки - бутан

Fig. 4. Yield of aromatic hydrocarbons formed over zeolite catalysts vs the conversion of the source gaseous raw materials: light symbol - propane, dark symbol - butane 
эта зависимость носит практически линейный характер. В то же время при конверсии бутана резкое увеличение выхода ароматических углеводородов наблюдается только при достижении достаточно высоких значений конверсии. Это означает, что в пределах точности измерений выход ароматических углеводородов на галлоалюмосиликате зависит от типа используемого углеводородного сырья. Для алюмосиликата заметное образование ароматических углеводородов происходит только при высоких значениях конверсии как пропана, так и бутана (более $70 \%$ ).

\section{Заключение}

Полученные экспериментальные данные свидетельствуют о высокой активности высококремнеземного цеолита в процессе превращения $\mathrm{C}_{3}, \mathrm{C}_{4}$-алканов и относительно невысокой селективности образования ароматических углеводородов. Введение на стадии гидротермального синтеза в состав цеолита галлия существенно повышает его активность в отношении образования целевого продукта. Для достижения на изученных катализаторах близкой конверсии пропана и бутана температура процесса превращения пропана должна быть на 50 градусов выше, чем при конверсии бутана, при одинаковых других условиях реакции.

Работа выполнена в рамках проекта № V.46.2.1 Программы фундаментальных научных исследований государственных академий наук.

\section{Список литературы}

1. Baerlocher C., McCusker L.B., Olson D.H. Atlas of Zeolite Framework Types. 6-th ed. New York: Elsevier Inc.. 2007. 398 p.

2. Frey K., Lubango L.M., Scurrell M.S., Guczi L. Light alkane aromatization over modified ZnZSM-5 catalysts: characterization of the catalysts by hydrogen/deuterium isotope exchange. Reaction Kinetics, Mechanisms and Catalysis. 2011. Vol. 104, P. 303-309.

3. Zaikovskii V.I., Vosmerikova L.N., Vosmerikov A.V. Nature of the Active Centers of In-, Zr-, and Zn-Aluminosilicates of the ZSM-5 Zeolite Structural Type. Russian Journal of Physical Chemistry. 2018. Vol. 92 (4), P. 689-695.

4. Gabrienko A.A., Arzumanov S.S., Freude D., Stepanov A.G. Propane Aromatization on ZnModified Zeolite BEA Studied by Solid-State NMR in Situ. Journal of Physical Chemistry C. 2010. Vol. 114, P. 12681-12688.

5. Gianetto G., Mongue R., Galiasso R. Transformation of LPG into aromatic hydrocarbons and hydrogen over zeolite catalysts. Catalysis Review - Science \& Engineering. 1994. Vol. 36(2), P. 274-304.

6. Восмериков А.В., Ерофеев В.И. Влияние механической обработки на каталитические свойства цеолитсодержащих катализаторов ароматизации низших алканов. Журнал физической химии. 1995. T. 69(5), C. 787-790. [Vosmerikov A.V., Erofeev V.I. Effect of mechanical treatment on the catalytic properties of zeolite catalysts for aromatization of lower alkanes. Russian Journal of Physical Chemistry A. 1995. Vol. 69(5), P. 787-790 (In Russ.)]

7. Paukshtis E.A., Yurchenko E.N. Study of the Acid-Base Properties of Heterogeneous Catalysts by Infrared Spectroscopy. Russian Chemical Reviews. 1983. Vol. 52(3), P. 242-258. 
8. Soltanov R.I., Paukshtis E.A., Yurchenko E.N. IR spectroscopic investigation of the thermodynamics of the reaction of carbon-monoxide with the surface of several oxide adsorbents. Kinetics and Catalysis. 1982. Vol. 23(1), P. 135-141. 